RRH: SHORT COMMUNICATIONS.

\title{
Galapagos Mockingbird (Mimus parvulus) Preys on an Invasive Mammal
}

Kiyoko M. Gotanda, ${ }^{1,4}$ Diana M.T. Sharpe, ${ }^{2}$ and Luis F. De Léon ${ }^{3}$

${ }^{1}$ Redpath Museum and Department of Biology, McGill University, Montréal, QC H3A 0C4, Canada.

${ }^{2}$ Smithsonian Tropical Research Institute, Naos Laboratories, Amador Causeway, P.O. Box 0843-03092, Panama City, Republic of Panama.

${ }^{3}$ Centro de Biodiversidad y Descubrimiento de Drogas, Instituto de Investigaciones Científicas y Servicios de Alta Tecnología (INDICASAT-AIP), PO Box 0843-01103, Panamąá 5. República de Panamáńt.

${ }^{4}$ Corresponding author; e-mail: kiyoko.gotanda@mail.mcgill.ca 
ABSTRACT.-Galapagos Mockingbirds (Mimus parvulus) are opportunistic feeders that have been observed engaging in a variety of unusual predatory behaviors. Here, we report on a specific behavior that we observed: a Galapagos Mockingbird preying on an invasive mammal by repeatedly hitting it on the ground. We discuss the reasons that the mockingbird may might have engaged in this behavior and the potential implications this could have for native biodiversity and conservation on the Galapagos Islands.

Key words: bashing, behavior, Galapagos, Mimus parvulus, predation, rodent. 
The Galapagos Mockingbird, Mimus parvulus, is found on most of the islands in the Galapagos archipelago, with separate sub-species described on San Cristobal, Floreana, and Española (Arbogast et al. 2006). M. parvulus are omnivorous birds that feed opportunistically on a wide variety of prey including fruit, flowers, insects, and lizards (Beebe 1924, Bowman and Carter 1971, Grant and Grant 1979). They have been observed engaging in a variety of unusual feeding behaviors including picking ticks off of marine iguanas (Carpenter 1966, Christian 1980), drinking blood from open sores (Curry and Anderson 1987, Christian 1980), picking at sea lion teeth (Trimble 1976), kleptoparasitizing from centipedes (Curry 1986), and eating seabird eggs (Hatch 1965, Harris 1968, Bowman and Carter 1971). Here, we report on the behavior of a Galapagos Mockingbird preying on a small rodent.

We made the following observation on Santa Cruz Island on 12 January 2014 at 1700 Galapagos Time (GALT) at the Charles Darwin Research Station (CDRS) in Puerto Ayora. We observed one Galapagos Mockingbird with a small rodent in its beak (Fig. 1). For $\sim 5$ mins mockingbird beat the rodent on the ground, grasping it either by the scruff of its neck, its snout, its ear, or its tail. The mockingbird would periodically drop the rodent to re-adjust the bite, and eventually the bird flew away with the dead rodent in its beak.

The behavior of the mockingbird hitting the mammal on the ground likely serves two purposes. The first is to kill a prey item (Johnsingh 1979) of proportionally large size, and the second is to "soften [it] up," presumably by breaking the bones within (Roberts 1961). This type of "bashing" behavior has been reported in a variety of species (Lefebvre et al. 2002), although not, to our knowledge, in the Galapagos Mockingbird. In addition to the present observation, we have also observed Galapagos Mockingbirds hit other large prey items on the ground, including centipedes (De Léon, L. F. pers. observ.) and caterpillars (Fig. 2). While we did not observe the 
Galapagos Mockingbird eating the rodent, mockingbirds are known to be omnivorous and have been observed eating the flesh of various animals such as sea lions and frigate birds (Bowman and Carter 1971), so it is plausible to assume that the mockingbird took the rodent somewhere to be eaten. However, more observations would be needed to confirm this.

With the assistance of several experts, we were able to identify the rodent the Galapagos Mockingbird was preying on as the invasive house mouse, Mus musculus. It is thought that $M$. musculus was introduced to Santa Cruz Island in the late 1940s (Kastdalen 1982), and is one of three introduced rodent species (in addition to Rattus rattus and $R$. norvegicus) on Santa Cruz (Key and Muñoz 1994). The abundance of M. musculus has since increased (Kastdalen 1982, Key and Muñoz 1994), with the most recent density estimates up to >30 mice/ha. In addition, recent surveys suggest that the endemic rodents on this island, Nesoryzomys indefessus and $N$. darwini, are considered extinct (Key and Muñoz 1994).

Our observation demonstrates that mockingbirds are able to adapt by consuming novel food items, which some consider evidence of innovation (Lefebvre et al. 1997). This behavioral flexibility in foraging could have played a role in the diversification of Mimus, the second most specious clade of the Galapagos Islands, by allowing birds to specialize in different feeding strategies and resources (Tebbich et al. 2010).

Our observation has potentially important implications for the management of introduced species and conservation of the native biodiversity of the Galapagos. First, introduced rodents such as the house mouse and ship rat can have negative effects on native organisms such as Opuntia sp. cacti by increasing mortality (Snell et al. 1994), as well as on seabirds by depredating their eggs and juveniles (Harris 1967, 1968; Key and Muñoz 1994; Wanless et al. 2007; Harper and Carrion 2011; Phillips et al. 2012). Thus, Galapagos Mockingbirds' ability to 
exploit abundant novel prey items could improve their resiliency in the face of the depletion of their native food base. Second, one reason that exotic species might thrive in their introduced range is because of a lack of natural predators (i.e., the Enemy Release Hypothesis; Elton 1958). If native species learn to recognize and prey on introduced species, this could potentially control the population growth of invasive species. Further research is needed to determine if mockingbirds' predation on mice, in conjunction with predation by Galapagos Hawks (Buteo galapagoensis) or owls, could significantly affect mice densities, or if our observation merely represents an isolated, rare foraging event. Finally, a number of management steps are being taken to eradicate invasive rodents from the Galapagos, including the deployment of poison (Harper and Carrion 2011, Key and Muñoz 1994). Our observation implies that measures should be undertaken to ensure that mockingbirds do not eat poisoned prey items (Harper and Carrion 2011, Campbell et al. 2013).

\section{ACKNOWLEDGMENTS}

Logistical support and permits were provided by Galapagos National Park Service and the Charles Darwin Foundation. We thank R. Dowler, A. Goldman, and V. Millien for assistance in identifying the rodent from digital photographs of the mouse in several positions. Financial support was provided by Earthwatch Institute, Sigma Xi, the National Science and Engineering Research Council of Canada in the form of a Vanier scholarship for KMG, Les Fonds Québécois de la Recherche sur la Nature et les Technologies (FQRNT) in the form of a post-doctoral scholarship to DS, and a grant from Sistema Nacional de Investigación (SNI) and Secretaría Nacional de Ciencia, Tecnología e Innovación (SENACYT) to LFD. We gratefully acknowledge 
J. Podos (aka "Papa Pinzón") and A. Hendry for introducing us to research on the Galapagos Islands. 


\section{LITERATURE CITED}

Arbogast, B. S., S. V. Drovetski, R. L. Curry, P. T. Boag, G. Seutin, P. R. Grant, B. R.

GRANT, AND D. J. ANDERSON. 2006. The origin and diversification of Galapagos

Mockingbirds. Evolution 60:370-382.

BEEBE, W. (1924). Galápagos: world's end. Putnam's Sons, New York, USA.

BOWMAN, R. I. AND A. CARTER. 1971. Egg-pecking behavior in Galapagos Mockingbirds. Living Bird 10:243-270.

CAMPBEll, K. J., V. CARRIÕN, AND C. SEVILla. 2013. Increasing the scale of successful invasive rodent eradications in the Galápagos Islands. Galápagos Report 2011-2012. GNPS, GCREG, CDF and GC. Puerto Ayora, Galápagos, Ecuador.

CARPENTER, C. C. 1966. The marine iguana of the Galápagos Islands, its behaviour and ecology. Proceedings of the California Academy of Sciences Ser. 4 34:329-376.

Christian, K. A. 1980. Cleaning/feeding symbiosis between birds and reptiles of the Galápagos Islands: new observations of inter-island variability. Auk 97:887-889.

CurRY, R. L. 1986. Galapagos Mockingbird kleptoparasitizes centipede. Condor 88:119-120.

CURRY, R. L. AND D. J. ANDERSON. 1987. Interisland variation in blood drinking by Galapagos Mockingbirds. Auk 104:517-521.

ELTON, C. S. 1958. The ecology of invasions by animals and plants. Methuen, London, UK.

GRANT, P. R. AND N. GRANT. 1979. Breeding and feeding of Galápagos mockingbirds, Nesomimus parvulus. Auk 96:723-736.

HARPER G. A, CABRERA L. F. 2010. Response of mice (Mus musculus) to the removal of black rats (Rattus rattus) in arid forest on Santa Cruz Island, Galápagos. Biological Invasions $12: 1449-1452$. 
HARPER, G. A. AND V. CARRION. 2011. Introduced rodents in the Galapágos: colonisation, removal and the future. Pages 63-66 in Island invasives: eradication and management (Veitch, C. R., M. N. Clout, and D. R. Towns, Veitch, C. R., M. N. Clout, and D. R. Towns Veitch, C. R., M. N. Clout, and D. R. Townss). IUCN, Gland, Switerzland. HARRIS, M. P. 1967. Sea bird research in Galápagos. Noticias de Galápagos 9/10:11-14. HARRIS, M. P. 1968. Egg-eating by Galápagos Mockingbirds. Condor 70:269-270.

HATCH, J. J. 1965. Only one species of Galápagos Mockingbird feeds on eggs. Condor 67:354356.

Johnsingh, A. J. T. 1979. A note on the predation of Jungle Myna (Acridotheres fuscus Wagler) on field mouse. Journal of the Bombay Natural Historical Society 76:159.

Kastdalen, A. 1982. Changes in the biology of Santa Cruz Island between 1935 and 1965. Noticias de Galápagos 35:7-12.

KEY, G. AND E. H. MuÑOZ. 1994. Distribution and current status of rodents in the Galápagos. Noticias de Galapágos 53:21-25.

LEFEBVRE, L., N. NicOlAKAKIS, AND D. BoIRE. 2002. Tools and brains in birds. Behaviour 139:939-973.

Lefebvre, L., P. Whittle, E. LASCARIS, AND A. FinKelstein. 1997. Feeding innovations and forebrain size in birds. Animal Behaviour 53:549-560.

Phillips, R. B., D. WiEdENFELD, AND H. SNELl. 2012. Current status of alien vertebrates in the Galápagos Islands: invasion history, distribution, and potential impacts. Biological Invasions 14:461-480.

RoBERTS, N. L. 1961. Kookaburra and rat. Emu 61:221-221. 
SNEll, H. M., H. L. SNell, AND P. StONE. 1994. Accelerated mortality of Opuntia on Isla Plaza Sur: another threat from an introduced vertebrate? Noticias de Galápagos 53:19-20.

TebBich, S, K. Sterelny, AND I. TESCHKE. 2010. The tale of the finch: adaptive radiation and behavioural flexibility. Philosophical Transactions of the Royal Society B: Biological Sciences 365:1099-1109.

TRIMBLE, S. A. 1976. Galapagos Mockingbird pecks at sea lion mouth. Condor 78:567.

Wanless, R. M., A. Angel, R. J. Cuthbert, G. M. Hilton, And P. G. RyAn. 2007. Can predation by invasive mice drive seabird extinctions? Biology Letters 3:241-244. 
FIG. 1. A Galapagos Mockingbird, Mimus parvulus, at the Charles Darwin Research Station on Santa Cruz Island with a house mouse, Mus musculus, in its beak. Photo courtesy of KMG.

FIG. 2. A Galapagos Mockingbird, Mimus parvulus, engaged in hitting a -caterpillar on the ground. Photo courtesy of KMG. 
Figure 1.

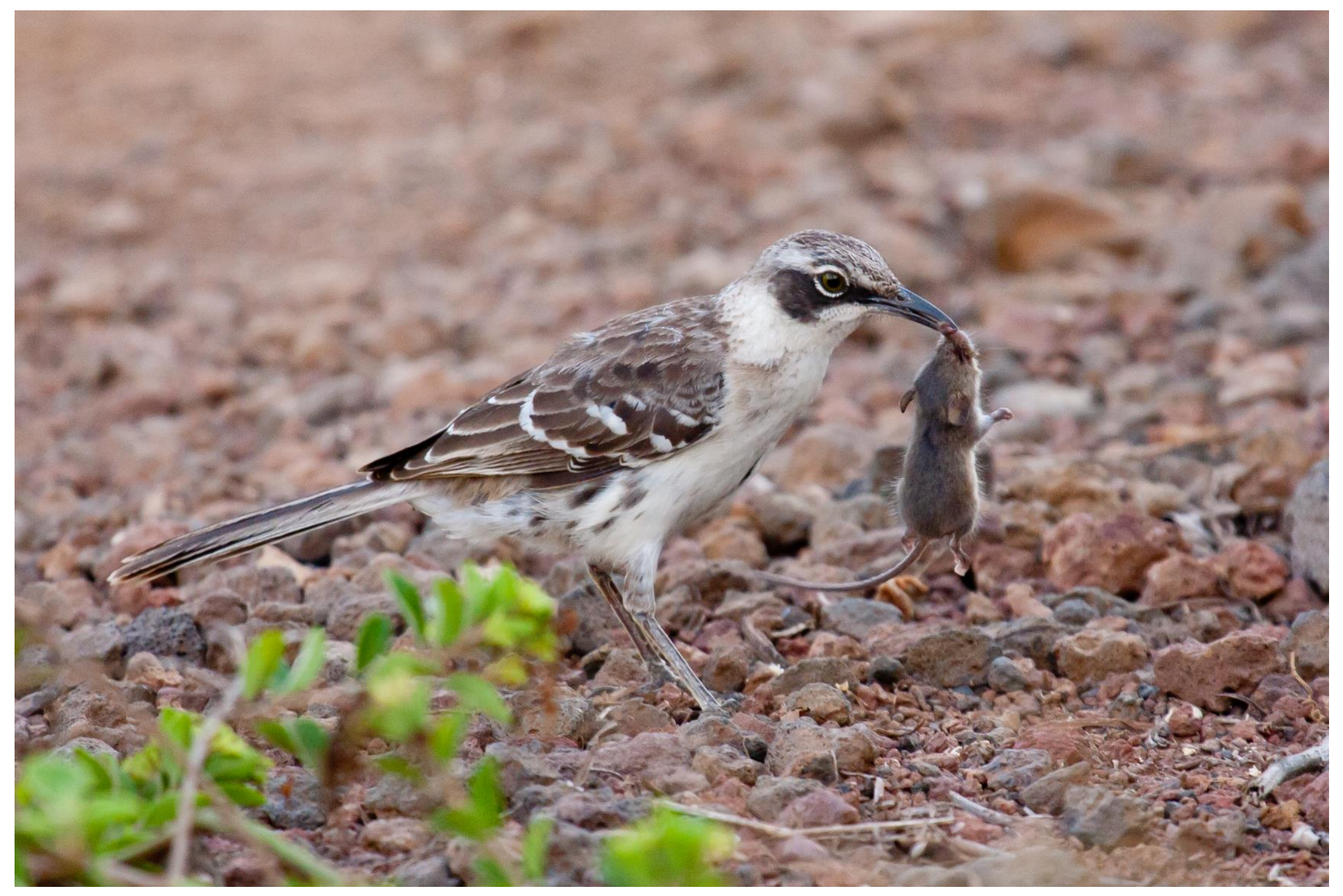


Figure 2.

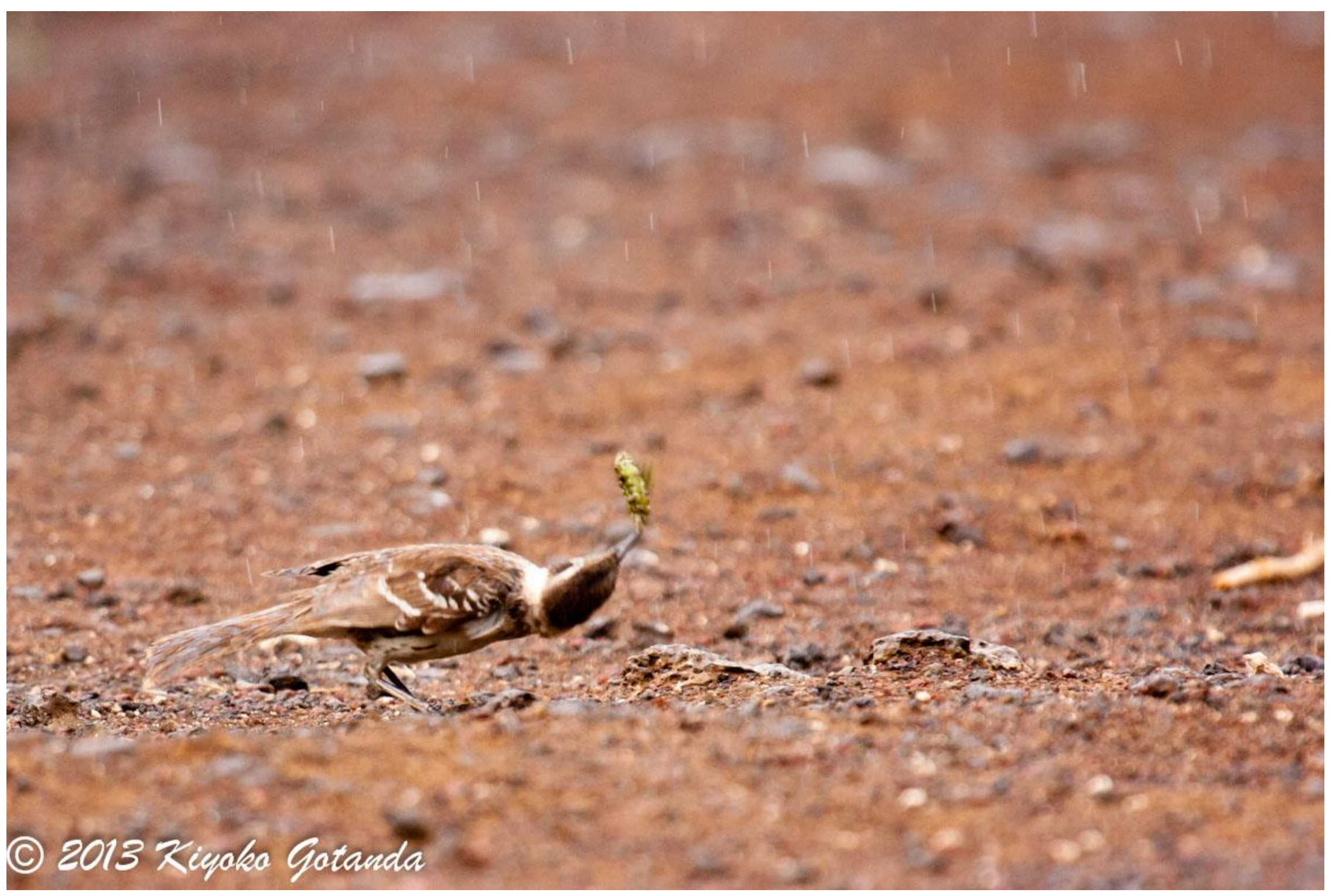

